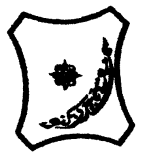

Bayero Journal of Pure and Applied Sciences, 11(2): 51 - 56

Received: November, 2018

Accepted: December, 2018

ISSN $2006-6996$

\title{
A REVIEW ON THE EFFECTS OF LAND USE ON WATER QUALITY AND USE: A CASE STUDY OF RIVER ROMI IN KADUNA STATE
}

\author{
Badiyya Hassan Mashi \\ Division of Science, School of Basic and Applied Science \\ Hassan Usman Katsina Polytechnic, Katsina \\ bdymashi@yahoo.com.
}

\begin{abstract}
Rapid changes in land use have been shown to have high impact on water quality and use. Access to portable water is necessary for all life and therefore, it is of paramount importance to investigate issues surrounding water availability and its usage. In this review, the effects of land use on the water quality of the River Romi in Kaduna State, Northwest Nigeria have been reviewed. This river is being utilised as a source of water for domestic and industrial consumption as these needs are not being met with any alternatives by the Nigerian government. However, literature has shown that rapid population increase and industrialisation have resulted in high levels of water contamination. Consequently, both physicochemical and biological parameters are above acceptable limits reported by researchers. It is recommended that best management practice (BMP) that uses different techniques such as source control, permeable paving using pervious concrete, storm water detention, storm water infiltration and vapourtranspiration in the treatment of wastewater be employed to reduce waste concentration going into the River, thereby lowering the risk of public health issues. Furthermore, it is recommended that Nigerian government agencies strictly impose regulatory sanctions to ensure effective waste management disposal.
\end{abstract}

Keywords: Land-use, Population, River Romi, Waste Water, Water quality,

\section{INTRODUCTION}

Land use transformation is very common in developing countries that have rapid human population growth and economies that are largely dependent on agriculture (Coale and Hoover, 2015). Land use transformation involves the management of changes to natural environments resulting from building settlements, industrialisation or increases in human activities within a specific area (Lambin and Geist, 2008). Such changes can lead to unwanted effects on the ecosystem that are believed to be the primary source of environmental pollution (Bates et al., 2008). They can also be significant contributors to lowquality river water within an area (Bates et al., 2008, Voulvoulis and Georges, 2015). Effects of land use change can be grouped as socioeconomical, ecological, hydrological or environmental (Anaba et al., 2016). According to Zuo et al., (2016), land use changes can lead to changes in the movement pattern of rivers due to endless variations in the distribution of runoff. River water quality can be reflective of activities within its catchment as well as anthropogenic land uses and climate and geomorphic processes
(Lespez et al., 2015). However, the link between river characteristics and water quality is not direct because most of the aforementioned factors are associated with time and space (Huang et al., 2015, Fu et al., 2014). For instance, water turbidity can occur if there is a high volume of livestock grazing on steep slopes due to surface runoff, with this being reversible if grazing occurs on flatter areas. Likewise, high applications of fertilizer may result in eutrophic rivers, especially when applied to sandy soils with high drainage density over a period of time (Lange et al., 2011, McComb and Davis, 1993). As water is one of the most important compounds on earth, its quality and usage is of paramount importance (Boyd and Tucker, 2012). Different sources of water including underground and seawater are recognised and it is primary usage within for example, industry and agriculture (reviewed by Cuo, 2016, Kounina et al., 2013). Similarly, most activities relating to its usage may at one point result in either improving or reducing the quality of the water (Priyadarshini et al., 2015, Zhang et al., 2014, Zia et al., 2013). 
It is therefore important to track the impact of land use on water quality, especially in developing countries where access to portable water can be very limited.

In this report, the effects of land use on the water quality of the River Romi in the catchment of River Kaduna in Northwest Nigeria have been analysed.

\section{Study area}

The River Romi is a branch of the River Rigasa and it is the major river that adds to guttering the area into the Kaduna river system (Figure 1). The River Kaduna is a main branch of the River Niger and it flows from $29 \mathrm{~km}$ south-west of Jos near Vom in a north-westerly direction to a bend $35 \mathrm{~km}$ northeast of Kaduna (Bununu et al., 2015). The river has many catchments including Romi, Juji and Guraran, among others. All the tributaries and streams within Kaduna State experience overflow throughout the rainy season and are mostly used for fishing and transport of local produce. Other identified applications of river water include swamp rice and sugarcane cultivation as well as domestic and industrial use (Abaje et al., 2016).

Although the River Romi's location was initially considered as a forest reserve in the early 1960s but later changed to industrial use with settlements around it. It was characterised by over $80 \%$ agricultural land use (Bununu et al., 2015). The Romi is commonly utilised for both domestic and agricultural purposes and it is the main source of water for consumption for people living in Romi and the surrounding settlements. Romi is under Chikun Local Government of Kaduna State. It has an area of $4,645 \mathrm{Km}^{2}$ and a population of 368,250 at the 2006 census. Most people living within the River Romi has utilised the river for dry season irrigation, smallscale fishing and as a source of drinking water for their animals (Ahmad, 2014; Ugya and Umar, 2015).

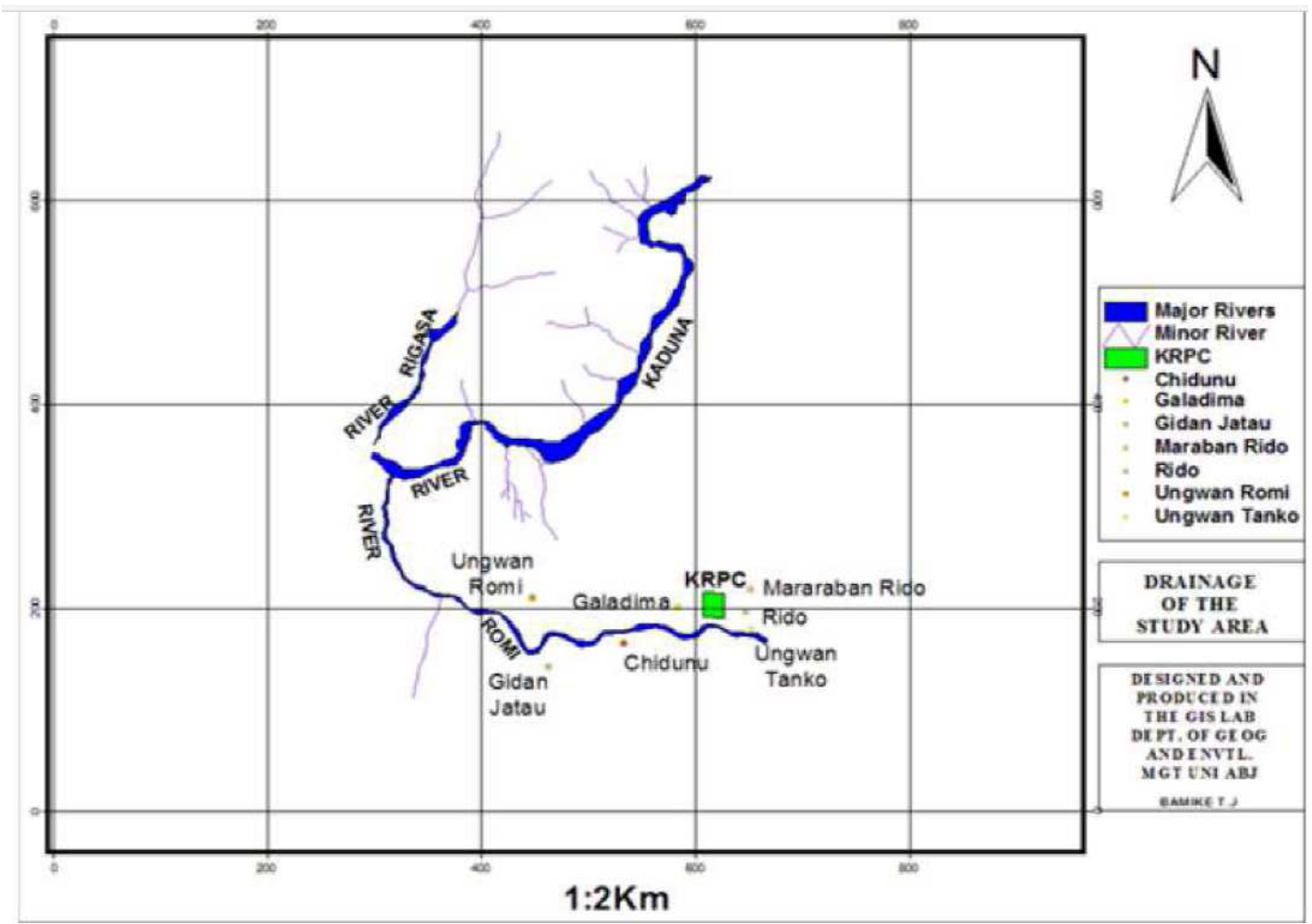

Figure 1: Map of River Kaduna and its catchments, after Ahmad, (2014).

The effect of land use on the River Romi's water quality and usage Water availability in the Romi area

Water is one of the most valuable natural resources due to its domestic and industrial importance. According to the Stellenbosch Law, water is a right and a commodity (Moyo, 2013).
Indeed, access to safe water is not only a right but also a necessity to sustain healthy life. Similarly, both quality and availability of water are crucial, even though a difficult relationship between water, water provision and water management exist (Moyo, 2013). 
BAJOPAS Volume 11 Number 2 December, 2018

Water occupies the largest portion of the planet, yet access to portable water in some areas including areas within Romi area remains a privilege. This is apparent even during the African raining season, when a high expectation of abundant water contrasts with portable water remaining a limited utility. Water shortages are in fact a global phenomenon affecting up to 2.8 billion people. In the Romi area of Nigeria for instance, despite the availability of large water bodies, access to portable water for consumption and other household activities is very low. Most areas in the Romi area close to rivers suffer water shortages, with people sometimes traveling up to $3 \mathrm{~km}$ to access safe water. This is due to many factors including poor government regulation, Agricultural activities, industrial activities, lack of treatment facilities and inadequate energy supplies (Ahmad, 2014). Agricultural activities such as fertiliser application, animal grazing has generally been identified as factors that could increase the Physicochemical properties of river water including its turbidity and nutrient content. Similarly, poor government policies such as poor monitoring of the refinery waste discharge has greatly influenced the contamination of the river. Crude oil waste discharge to the river may greatly add more complications to the treatment process. According to Ahmad (2014), factors such as pollution, deforestation, landscape change, urbanization among others affect water availability. The rate of pollution and increase industrialisation and settlement growth are currently affecting the availability of water in Romi area.

\section{Sources of water pollution}

Despite the previously mentioned factors affecting the availability of portable water to the Romi area, the River Romi was utilised successfully for portable water up until a decision was made to set up the Nigerian Oil Refinery (Kaduna Refinery) within its area (Ahmad, 2014, Osuide, 1990). Some literature belief that the location of this refinery was primarily to allow the discharge of liquid refinery waste into the River Romi (Ahmad, 2014; EMEASO, 2011; Ugya et al., 2015), and a number of studies have confirmed frequent contamination of the River Romi by the refinery (Ugya et al., 2016). Furthermore, pollution of the river as a result of excessive nutrients from agricultural activities has also been reported. This is in addition to a rapid increase in population and industrialisation that has resulted in massive drains of municipal and industrial wastewater pouring into the river. This discharge, especially if untreated, can lead to multiple environmental risks for farming, drinking and sustenance of aquatic life (Obilonu et al., 2013). Such discharge water can also contain heavy metals in addition to biological contaminations, thereby resulting in pollution of crops and contamination of groundwater when used for irrigation farming, with resulting potential public health concerns (Rheingans et al., 2006).

Water quality is usually presented in terms of biological and physicochemical parameters. Depending on its intended use, there are standard acceptable limits for each parameter set by the World Health Organization. In the majority of cases, river water quality is described in terms of for example, dissolved oxygen, $\mathrm{pH}$, temperature and the most probable number (MPN) of coliforms (WHO, 2008). Poor water quality due to environmental pollution is a major concern to public health, especially in developing and underdeveloped countries where drinking water quality is often poorly managed and monitored (Kraft, 2015).

A study by Lekwot et al., (2012) shows high level of total dissolved solids (TDS), total suspended solids (TSS), dissolved oxygen (DO), $\mathrm{pH}$, oil and grease, chemical oxygen demand (COD), electrical conductivity, temperature, turbidity, heavy metals and polyaromatic hydrocarbon in water samples obtained from the River Romi between 2010 and 2011. The results further show that all the physicochemical parameters except oil, grease and $\mathrm{pH}$ were $100 \%$ and $120 \%$ higher than the maximum permissible limit approved by the World Health Organization (WHO) (Lekwot et al., 2012). This is in contrary to a recent study by Liman and Rabi'u (2018) who investigated the physicochemical parameters of the river Romi and found that BOD, Turbidity, COD, and Phosphates to be above NESREA and WHO while $\mathrm{pH}$, Dissolve Oxygen, Nitrate, Nitrite, Sulphate, Sulphide, TDS, Conductivity and Temperature values were found to be within the standard limit (Liman and Rabi'u, 2018). Similarly, Adeniyi et al. (2017) has suggested that River Romi contamination is varies from location to locations. The study reveals that the river upstream contains low level of contamination which are mostly within the standard limit. However, the downstream is likely to be more contaminated due to high increase of effluent discharge (Adeniyi et al., 2017). This is in reflection of the large volume of discharge to the river, thereby indicating a potential threat to public health. 
Water pollution has severe consequences on both aquatic life and agricultural activities and leads to a loss in biodiversity and food chain related issues (Schwarzenbach et al., 2006). Over 2.3 billion of the world's population are suffering from water-related diseases, with over 2.2 million people dying every year due to poor drinking water and inadequate sanitation (Gleick, 2004, Rheingans et al., 2006). Although industrialisation is inevitable, proper waste management and land use must be maintained to ensure the safety of local populations and their industries.

An investigation into pollution incidents by three Nigerian Government agencies (the Nigerian National Petroleum Company (NNPC), the National Environmental Standard and Regulation Enforcement Agency (NESREA) and the Kaduna Environmental Protection Agency (KEPA) reveals no evidence of illegal contamination of the River Romi. This is in spite of a World Bank independently sponsored study of contamination of the River Kaduna showing empirical evidence of pollution from the River Romi (Al-Amin, 2013). Moreover, investigation into the activities of the Kaduna Refinery and Petrochemical Company (KRPC) revealed that it has not had solid waste treatment or disposal facilities throughout its operational history, with the refinery discharging all of its waste into the River Romi (Al-Amin, 2013). In fact, the only treatment process currently applied to KRPC's raw water is disinfection, which could result in a high accumulation of heavy metals and a potential hazard to aquatic life, as well as longtime public health concerns (Lekwot et al., 2012).

\section{Control measures}

In order to control the impact of the land use on the River Romi, the Government needs to ensure proper waste disposal by the industries. NESREA and KEPA should ensure industrial compliance to avoid the high load of contamination into the River. Ideally, the best practice to control pollution while ensuring sustainability in the Romi area would be to employ modern practices. These practices could be Sustainable Urban Drainage Systems (SUD) or Best Management Practice (BMP) that use different techniques such as source control, permeable paving using pervious concrete, storm water detention, storm water infiltration

\section{REFERENCES}

Abaje, I.B., Sawa, B.A., Iguisi, E.O. and Ibrahim, A.A. (2016). Impacts of climate change and adaptation strategies in rural and vapour-transpiration in the treatment of wastewater before discharge (Ugya et al., 2016). These techniques are designed to drain dirty and surface water runoff via collection, storage and cleaning before discharging it into a river. The advantage of these methods is that they are cost-efficient and can replace more conventional methods that can result in flooding and pollution of the environment with resultant harm to wildlife and contamination of groundwater (Hua and Liu, 2012). SUD and BMP have been utilised successfully in countries including the United Kingdom, the United States of America and Australia. Other areas worthy of consideration include improving highway runoff, implementing sanctions for non-compliance of stipulated regulations to defaulting industries and an enlightenment campaign on the dangers of environmental pollution (Kumar, 2014).

Despite the volume of contamination experienced by the River Romi, it is possible to process its water for public consumption. This process could involve stages such as pumping, screening for floating objects, storage to dilute and improve water quality, settling of debris and solid contaminants and the breakdown of organic materials by microorganisms. Other stages to follow would include coagulation and flocculation, sedimentation, filtration and disinfection. These processes are critical in ensuring water is safe for public consumption (Banjoko et al., 2016).

\section{CONCLUSION AND RECOMMENDATIONS}

Over the years, the River Romi has endured waste discharge from industrial, agriculture and domestic sources that possess a threat to public health. It is sad to note that the Nigerian government is not actively pursuing adherence to regulations related to this on-going pollution. Consequently, it is recommended that regulatory agencies should more proactively check the activities of KRPC and other industries around the River Romi to ensure adherence to regulations. Moreover, there is a need for the Nigerian government to establish a waste processing plant to help reduce the concentration of waste going into the river. Finally, it is recommended that a water treatment plant be constructed in the area to increase portable water availability.

$\begin{array}{lcr}\text { communities of } & \text { Kaduna } & \text { State, } \\ \text { Nigeria. Ethiopian } & \text { Journal } & \text { of } \\ \text { Environmental } & \text { Studies } & \text { and } \\ \text { Management, } g(1), \text { pp.97-108. } & \end{array}$


BAJOPAS Volume 11 Number 2 December, 2018

Adeniyi, O.D., Adediran, A.A., Adeniyi, M.I., Yahya, M.D., Afolabi, E.A., Adebayo, I.T., Ojo, A., Efeovbokhan, V., Ayoola, A.A. and Ojewumi, M.E. (2017). Evaluation of the impact of Kaduna Refinery effluent on River Romi. Nigerian Journal of Technological Research, 12(1), pp.17-21.

Ahmad, H. A. (2014). Determination of effectiveness of waste water (effluent) treatment process of Kaduna Refinery and Petrochemical Company (KRPC), Nigeria. Abubakar. 1(1): pp.6-12.

Al-Amin, M. A. (2013). Energy Production and Environmental Concerns in Nigeria: The Case of Kaduna Petroleum Refinery on its Host Community. Energy. 3(10).

Anaba, L.A., Banadda, N., Kiggundu, N., Wanyama, J., Engel, B. and Moriasi, D. (2016). Application of SWAT to assess the effects of land use change in the Murchison Bay catchment in Uganda. Computational Water, Energy, and Environmental Engineering, 6(01), p.24.

Banjoko, B., Kameswara, M. and Sridhar, C. (2016). Upgrading Wastewater Treatment Systems for Urban Water Reuse.

Bates, B., Kundzewicz, Z. and Wu, S. (2008). Climate change and water. Intergovernmental Panel on Climate Change Secretariat.

Boyd, C. E. and Tucker, C. S. (2012). Pond aquaculture water quality management. Springer Science \& Business Media.

Bununu, Y., Ludin, A. and Hosni, N. (2015). City profile: Kaduna. Cities. 49: pp.53-65.

Coale, A. J. and Hoover, E. M. (2015). Population growth and economic development. Princeton University Press.

Cuo, L. (2016). Land use/cover change impacts on hydrology in large river basins: a review. Terrestrial Water Cycle and Climate Change: Natural and HumanInduced Impacts. 221: pp.103.

EMEASO, O. I. (2011). Pollution and Self Purification Studies of River Romi, Chikun Local Government Area Kaduna State.

Fu, J., Zhao, C., Luo, Y., Liu, C., Kyzas, G.Z., Luo, Y., Zhao, D., An, S. and Zhu, H. (2014). Heavy metals in surface sediments of the Jialu River, China: their relations to environmental factors. Journal of hazardous materials, 270, pp.102-109.
Gleick, P. H. (2004). Milennium development goals for water: crucial objectives, inadequate commitments. The World's Water 2004-2005: The Biennial Report on Freshwater Resources. : pp.1.

Hua, X. and Liu, Z. (2012). Urban stormwater landscape: improvement and integration.

Huang, J., Huang, Y., Pontius, R.G. and Zhang, Z. (2015). Geographically weighted regression to measure spatial variations in correlations between water pollution versus land use in a coastal watershed. Ocean \& Coastal Management, 103, pp.14-24.

Kounina, A., Margni, M., Bayart, J.B., Boulay, A.M., Berger, M., Bulle, C., Frischknecht, R., Koehler, A., i Canals, L.M., Motoshita, M. and Núñez, M. (2013). Review of methods addressing freshwater use in life cycle inventory and impact assessment. The International Journal of Life Cycle Assessment, 18(3), pp.707-721.

Kraft, M. (2015). Environmental policy and politics. Routledge.

Kumar, L. (2014). The Impact of Corporate Social Responsibility on Sustainable Development.

Lambin, E. F. and Geist, H. J. (2008). Land-use and land-cover change: Local processes and global impacts. Springer Science \& Business Media.

Lange, K., Liess, A., Piggott, J.J., Townsend, C.R. and Matthaei, C.D. (2011). Light, nutrients and grazing interact to determine stream diatom community composition and functional group structure. Freshwater Biology, 56(2), pp.264-278.

Lekwot, V. E., Caleb, A. I. and Ndahi, A. K. (2012). Effects of effluent discharge of Kaduna Refinery on the Water Quality of River Romi.

Lespez, L., Viel, V., Rollet, A.J. and Delahaye, D. (2015). The anthropogenic nature of present-day low energy rivers in western France and implications for current restoration projects. Geomorphology, 251, pp.6476.

Liman, M. G. and Rabi'u S. M. (2018). Physicochemical Analysis of Raw Water From Romi River (A Tributary of Kaduna River), Kaduna State. Nigeria. IOSR Journal of Environmental Science, Toxicology and Food Technology (IOSRJESTFT). 12(3)1 PP 11-14 
BAJOPAS Volume 11 Number 2 December, 2018

McComb, A. and Davis, J. (1993). Eutrophic waters of southwestern Australia. Nutrient Cycling in Agroecosystems. 36(2): pp.105-114.

Moyo, K. (2013). Water as a Human Right Under International Human Rights Law: Implications for the Privatisation of Water Services.

Obilonu, A.N., Chijioke, C., Igwegbe, W.E., Ibearugbulem, O.I. and Abubakar, Y.F. (2013). Water quality challenges and impact. International Letters of Natural Sciences, 4.

Osuide, S. O. (1990). Environmental pollution in Nigeria. Habitat International. 14(1): pp.5-15.

Petrovic, M., Radjenovic, J. and Barcelo, D. (2011). Advanced oxidation processes (AOPs) applied for wastewater and drinking water treatment. Elimination of pharmaceuticals. The Holistic Approach to Environment. 1(2): pp.63-74.

Priyadarshini, K.V.R., Prins, H.H., de Bie, S., Heitkönig, I.M., Woodborne, S., Gort, G., Kirkman, K., Ludwig, F., Dawson, T.E. and de Kroon, H. (2016). Seasonality of hydraulic redistribution by trees to grasses and changes in their water-source use that change tree-grass interactions. Ecohydrology, 9(2), pp.218-228.

Rheingans, R., Dreibelbis, R. and Freeman, M. (2006). Beyond the Millennium Development Goals: public health challenges in water and sanitation. Global Public Health. 1(1): pp.31-48.

Schwarzenbach, R.P., Escher, B.I., Fenner, K., Hofstetter, T.B., Johnson, C.A., Von Gunten, U. and Wehrli, B. (2006). The challenge of micropollutants in aquatic systems. Science, 313(5790), pp.10721077.
Ugya, A. Y., Tahir, S. M. and Imam, T. S. (2015). The efficiency of Pistia stratiotes in the phytoremediation of Romi stream: A case study of Kaduna refinery and petrochemical company polluted stream. Int.J.Health Sci.Res. 5: pp.492-497.

Ugya, A., Tahir, S. and Imam, T. (2016). Emerging Trend in the Remediation of Pollution.

Ugya, A.Y. and Umar, S.A. (2015). A review on the pollution and phytoremediation of Romi stream. IOSR J. Pharm. Biol. Sci, 10, pp.25-29.

Voulvoulis, N. and Georges, K. (2015). Industrial and Agricultural Sources and Pathways of Aquatic Pollution. Impact of Water Pollution on Human Health and Environmental Sustainability. : pp.29.

World Health Organization and InterOrganization Programme for the Sound Management of Chemicals (2008). Uncertainty and data quality in exposure assessment. World Health Organization.

Zhang, W., Huang, B. and Luo, D. (2014). Effects of land use and transportation on carbon sources and carbon sinks: A case study in Shenzhen, China. Landscape and Urban Planning. 122: pp.175-185.

Zia, H., Harris, N.R., Merrett, G.V., Rivers, M. and Coles, N. (2013). The impact of agricultural activities on water quality: A case for collaborative catchment-scale management using integrated wireless sensor networks. Computers and electronics in agriculture, 96, pp.126138.

Zuo, D., Xu, Z., Yao, W., Jin, S., Xiao, P. and Ran, D. (2016). Assessing the effects of changes in land use and climate on runoff and sediment yields from a watershed in the Loess Plateau of China. Science of the Total Environment, 544, pp.238-250. 